\title{
Dependence on smell of social and overpopulation effects in the white rat
}

\author{
BRUCE JOHN MORRISON, HAL FORMAN, CONNIE HARRIS, and JAMES HOGAN \\ Miami University, Oxford, Ohio 45056
}

Sixty-four albino rats were obtained at 30 days of age, and half of them had their olfactorial bulbs aspirated. Two weeks later half of the Ss were housed in groups of 4 per cage and half in groups of 16 per cage. After 6 weeks all Ss were tested both individually and in groups in a counterbalanced manner in an open field where seven indices of emotionality were recorded. The results showed that smell is the dominant, if not sole, cue to group reduction of emotionality in the white rat. It is not, however, responsible for the increased emotionality found in overpopulated rats. The abnormal social behavior in overpopulated rats, however, tends to be eliminated by loss of smelling ability.

Morrison \& Hill (1967) found that white rats tested in groups of three in an approach-avoidance conflict were less emotional than white rats tested individually in the same situation. Morrison \& Thatcher (1969), in a study which replicated the biological and psychological effects of overpopulation in white rats, found that this group reduction of emotionality did not exist for those animals raised under high densities of 16 or 32 Ss per cage, though it was found for the animals housed 1 or 4 per cage. Ropartz (1968) has shown that the increased adrenal weights usually associated with fighting in mice can be caused solely by the odor of another mouse. Overpopulation in rats also. shows increased adrenal weight. The present experiment attempts to find out the effect of smell on the overpopulation effect, the group testing effect, and the Overpopulation by Group Testing interaction.

\section{METHOD}

Sixty-four albino rats were obtained at 30 days of age, and half of them had their olfactorial bulbs aspirated. Two weeks later half of the Ss were housed in groups of 4 per cage and half in groups of 16 per cage, with food and water ad lib.

All cages measured $17 \times 10 \times 7$ in. and were constructed of metal with screen on the front and bottom. Auditory and olfactory, but not visual or tactual, interaction was possible between cages. After 6 weeks all Ss were tested both individually and in groups in a counterbalanced manner in an open field where seven indices of emotionality were recorded.

The open field measured $45 \times 45$ in. and had 21-in sides. It was painted black and ruled into 9 -in. squares.

Recording was done on an Esterline-Angus event recorder, which recorded the occurrence and duration of:
(1) center entry $-S$ is in a square that does not have a wall along its border; (2) corner occupancy-S is in one of the four corner squares; (3) movement-the number of lines S crossed; (4) rearing-either against the wall or free rearing; (5) grooming; (6) freezing-S spends more than $5 \mathrm{sec}$ crouching in an immobile position; (7) defecation. The data were then analyzed, using an analysis of variance with $1 / 56 \mathrm{df}$ and $5 \%$ significance level.

\section{RESULTS}

From inspection of the intercorrelations of the behavioral indices, two response patterns emerged. One pattern was characterized by short length of time in corner occupancy, high number of squares entered, high number of times standing, high number of center entry, short length of time freezing, and long length of time grooming. This was operationally defined as low emotionality; this conforms to previous studies and the observation of the E. High emotionality was indicated by the opposite.

\section{Physiological}

The physiological changes due to overpopulation were found to replicate the previous findings of Thiessen (1964) and Christian (1961). Animals raised 16 per cage for overpopulation conditions were found to weigh less $(F=3.96)$. Overpopulated Ss also had smaller adrenal weights $(F=3.19)$. However, the body-weight/adrenal-weight ratio showed that overpopulated Ss had a higher adrenal weight per body weight than the animals housed in normal conditions. Olfactorial bulb removal operations had no effect upon the body weight or adrenal weight of the Ss.

Group Reduction of Emotionality

The findings of Morrison \& Hill (1967) were also replicated in that the group-tested animals showed less emotionality than did individually tested animals. Group-tested animals crosse more lines $(F=11.65)$, reared le: $(F=5.18)$, and spent less time in th corner $(F=6.61)$ than did individuall tested animals.

Density-Testing Interaction

This experiment replicates the Morriso \& Thatcher (1970) study in tha overpopulated Ss were more emotion: when group tested as opposed to th normal-rearing-condition Ss, who were les emotional when group tested Overpopulated Ss spent more time in th corner when group tested $(\mathrm{F}=14.29)$ overpopulated $\mathrm{S} s$ also crossed fewer line when group tested, as opposed to individually tested.

Effect of Bulbus

Olfactorius Removal

There was no significant main effect o the operation on body weight, adrena weight. or the ratio of these two. Tht inability to smell also had no effect on any of the overpopulation effects. Olfactoria bulb removal did, however, effect the Ss social behavior. Ss without the ability tc smell behaved in a group exactly like they behaved individually. This is shown by significant Operation by Testing interactions for number of lines crossec $(F=6.82)$ and for amount of time in the corner $(F=6.71)$.

Olfactorial bulb removal also tended tc eliminate the abnormal social behavior exhibited by rats housed in high densities (number of lines $F=5.32$, with other indices of emotionality showing a tendency toward elimination of the Testing by Density effect with operation).

\section{CONCLUSION}

Smell is the dominant, if not sole, cue to group reduction of emotionality in the white rat. It is not, however, responsible for the increased emotionality found in overpopulated rats as would be suggested by the work of Ropartz. On the other hand, abnormal social behavior in overpopulated rats tends to be eliminated by loss of smelling ability.

\section{REFERENCES}

CHRISTIAN, J. J. Phenomena associated with population density. Proceedings of the National Academy of Science, 1961, 47, 428-449.

MORRISON, B. J., \& HILL, W. F. Socially facilitated reduction of the fear response in rats raised in groups or isolation. Journal of Comparative \& Physiological Psychology, $1967,63,71-76$.

MORRISON, B. J., \& THATCHER, K. Overpopulation effects on social reduction of emotionality in the albino rat. Journal of Comparative \& Physiological Psychology, $1969,69,658-662$.

ROPARTZ, P. The relation between olfactory stimulation and aggressive behaviour in mice Animal Behaviour, 1968, 16, 97-100.

THIESSEN, D. D. Population density and behavior. Texas Reports of Biological Medicine, 1964, 22, 266-314. 